\title{
Jurist-Diction
}

Volume 1 No. 1, September 2018

Article history: Submitted 4 August 2018; Accepted 15 August 2018; Available online 3 September 2018

\section{TANGGUNG GUGAT LABEL REKAMAN DALAM PERJANJIAN KERJASAMA REKAMAN ARTIS DAN PERJANJIAN MANAJEMEN ARTIS}

\begin{abstract}
Alrido Pradanar
alrido.pradanar-13@fh.unair.ac.id Universitas Airlangga

Abstract

The freedom of every person to express their interest in music has led to financial gain. This is marked by the emergence of record labels in the music industry that accommodate the activities of every songwriter and artist. Artists who are performers have a great opportunity in establishing cooperation with record labels both in the form of recording songs and management of work related to his profession as a performer. In practice, however, there are often violations of the contract clause by the record label. Based on this background, there are two main problems that can be formulated, namely the legal relations of the parties in the artist's recording contract and artist management contract, and the parties' legal remedies in the artist's recording contract and artist management contract. The research method that used is statute approach and conceptual approach. Both of these approaches are used to examine and analyze the issues that are the object of discussion. The statute approach is conducted by reviewing all laws and regulations relevant to the legal issues that were addressed. The result of the study is an argument to solve the legal issues faced. Artist recording cooperation contract and artist management contract are two standard contracts that become one unity. In the reality that is lived, it cannot escape from the deficiencies upon the lack of fulfilment record label obligation that resulted in losses, especially on the artist side that has a position under the record label as a large company. The lack of a dispute settlement forum option clearly leads to a possible effort that can be done is a submission lawsuit to a court. Keywords: Artist Recording Cooperation Contract; Artist Management Contract; Liability of Loss.
\end{abstract}

\begin{abstract}
Abstrak
Kebebasan setiap orang untuk mengekspresikan minat mereka pada musik telah menghasilkan keuntungan finansial. Ini ditandai dengan munculnya label rekaman di industri musik yang mengakomodasi kegiatan setiap penulis lagu dan artis. Artis yang berprofesi memiliki peluang besar dalam menjalin kerja sama dengan label rekaman baik dalam bentuk rekaman lagu dan manajemen pekerjaan yang terkait dengan profesinya sebagai pemain. Namun dalam prakteknya, sering ada pelanggaran klausul kontrak oleh label rekaman. Berdasarkan latar belakang ini, ada dua masalah utama yang dapat dirumuskan, yaitu hubungan hukum para pihak dalam kontrak rekaman artis dan kontrak manajemen artis, dan upaya hukum pihak-pihak dalam kontrak rekaman artis dan kontrak manajemen artis. Metode penelitian yang digunakan adalah pendekatan statuta dan pendekatan konseptual. Kedua pendekatan ini digunakan untuk memeriksa dan menganalisis isu-isu yang menjadi objek diskusi. Pendekatan undang-undang dilakukan dengan meninjau semua undang-undang dan peraturan yang relevan dengan masalah hukum yang ditangani. Hasil dari penelitian ini adalah argumen untuk memecahkan masalah hukum yang dihadapi. Kontrak kerja sama perekaman artis dan kontrak manajemen artis adalah dua kontrak standar yang menjadi satu kesatuan. Dalam kenyataan yang dihayati, ia tidak bisa lepas dari kekurangan pada kurangnya kewajiban label rekaman pemenuhan yang mengakibatkan kerugian, terutama pada pihak artis yang memiliki posisi di bawah label rekaman sebagai perusahaan besar. Kurangnya opsi penyelesaian forum perselisihan jelas mengarah pada upaya yang mungkin dapat dilakukan adalah mengajukan gugatan ke pengadilan.
\end{abstract}

Kata Kunci: Kontrak Kerja Rekaman Artis; Kontrak Manajemen Artis; Kewajiban Kerugian. 


\section{Pendahuluan}

Perusahaan label rekaman tidak secara eksplisit dijelaskan dalam Undang - Undang Nomor 28 Tahun 2014 tentang Hak Cipta (selanjutnya disebut UU Hak Cipta), namun tugas dan kegiatannya secara jelas ditujukan sebagai lembaga dalam pendistribusian sebagaimana yang dijelaskan dalam Undang - Undang Hak Cipta bahwa "Pendistribusian adalah penjualan, pengedaran, dan/atau penyebaran Ciptaan dan/atau produk Hak Terkait.” Dalam praktiknya, perusahaan label rekaman tidak hanya bertindak sebagai lembaga pendistribusian (publisher) namun juga sebagai manajer yang mengatur seluruh kegiatan artis yang berhubungan dengan keprofesiannya baik secara off air maupun on air. Tak lain halnya dengan PT. Sony Music Entertainment Indonesia (selanjutnya disebut Sony Music) sebagai salah satu perusahaan label rekaman terbesar yang telah banyak melahirkan artis di industri musik Indonesia. Untuk menunjang kegiatan bisnisnya di industri musik, Sony Music memiliki lisensi yang sah dalam mengelola lagu dan mengatur seluruh kegiatan artis.

Bila mengacu pada UU Hak Cipta, artis dapat diartikan sebagai ,pelaku pertunjukan"e yang memiliki definisi "seorang atau beberapa orang yang secara sendiri - sendiri atau bersama - sama menampilkan dan mempertunjukkan suatu ciptaan." Untuk memformulasikan perwujudan atas kehendak antara pihak label rekaman dan artis secara terperinci, maka dibentuklah suatu perjanjian yang sering disebut sebagai „kontrak eksklusif.“ Perjanjian ini dibuat dengan judul Kerjasama Rekaman Artis dan Manajemen Artis.

Jika kita menganalisa secara hukum keperdataan, kegiatan yang dilakukan baik oleh pihak Sony Music maupun pihak artis timbul atas dasar perikatan yang terjadi. Dalam buku III BW tentang perikatan sendiri tidak menjelaskan definisi perikatan secara eksplisit, namun justru diawali dengan Pasal 1233 BW yang menjelaskan mengenai sumber - sumber perikatan. Dengan demikian, kontrak/ perjanjian merupakan salah satu dari dua dasar hukum yang ada selain undang undang yang dapat menimbulkan perikatan. ${ }^{1}$

\footnotetext{
1 Agus Yudha Hernoko, Hukum Perjanjian Asas Proporsionalitas dalam Kontrak Komersial, Kencana Prenamedia Group, Jakarta, 2014.[19].
} 
Pembuatan klausula - klausula dalam perjanjian rekaman artis dan perjanjian manajemen artis dilakukan sepenuhnya oleh Sony Music. Artis sebagai pihak kedua dalam hal ini mengetahui, menyetujui dan menjalankan apa yang menjadi kewajibannya. Namun demikian seakan tidak pernah berhentinya muncul anggapan bahwa kontrak yang terjalin antara label rekaman musik dan artis tidak memberikan posisi yang seimbang. ${ }^{2}$ Ketimpangan ini membuat sering dirugikannya pihak artis dalam beberapa hal terutama mengenai hak - hak yang telah tercantum dalam klausula perjanjian.

Disisi lain luputnya pihak label rekaman musik dalam memenuhi beberapa hal yang diperjanjikan membuat kerugian pihak artis semakin nyata. Misalnya dalam pelaksanaan perjanjian rekaman artis Sony Music, biaya akomodasi atas promo lagu yang dilakukan di luar tempat tinggal artis merupakan tanggungan sepenuhnya pihak Sony Music namun yang terjadi ketika artis berdomisili di luar Jakarta, Sony Music tidak memberikan penggantian biaya sedikitpun atas akomodasi tersebut. Contoh lain yang menjadi sorotan dalam perjanjian manajemen artis Sony Music, bahwa pihak manajemen mengingkari kewajiban yang telah tercantum dalam klausula untuk berusaha mencarikan pekerjaan terhadap artis, lebih lanjut dalam hal artis menerima beberapa tawaran pekerjaan atas dirinya sendiri dan telah sepenuhnya dilimpahkan kepada manajer sebagai kuasa, tidak ada satupun tawaran pekerjaan yang memperoleh kesepakatan. Hal ini sangat disayangkan karena artis harus kehilangan kesempatan dalam memperoleh pekerjaan.

\section{Industri Musik Indonesia}

Industri musik merupakan peluang bisnis di bidang karya musik yang terbuka dan bisa dilakukan oleh siapa saja. Para musisi yakin bahwa karya musik dapat membawa keuntungan, mereka berlomba - lomba menciptakan karya musik berupa lagu dengan berbagai macam genre untuk dipulikasikan. Berbagai macam media publikasi dan pemasaranpun semakin berkembang tak hanya dalam bentuk fisik namun juga digital. hasil studi mencatat bahwa dari tahun ke

${ }^{2}$ Ibid, hal 25 . 
tahun, pembeli produk musik dalam format digital dengan menggunakan iTunes Store makin bertambah angkanya. Pada tahun 2012 tercatat, toko digital yang dimiliki Apple ini sukses menguasai 64 persen dari pangsa pasar musik online di dunia. ${ }^{3}$ Keadaan ini membuat niat untuk mencari peruntungan di industri musik semakin nyata.

Namun bukan sebuah hal yang mudah untuk menembus industri musik. Adapun karya - karya musik harus memperoleh penanganan pihak label rekaman agar bisa terpublikasi dengan baik. Seperti halnya Sony Music yang menjadi salah satu label rekaman di tanah air. Beberapa artis yang berada dibawah naungan Sony Music yaitu Judika, Fatin, Gita Gutawa, Isyana Sarasvati, GAC, The Overtunes dan masih banyak yang lain. Namun, Sony Music tidak hanya melakukan produksi rekaman artis nasional tetapi juga banyak melakukan rekaman untuk artis luar negeri atau internasional.

Dalam hal ini Sony Music tidak hanya melakukan rekaman musik untuk didistribusikan melalui kaset, $\mathrm{CD}$, vinyl tetapi juga melalui digital. Pemasaran yang dilakukan oleh Sony Music tidak hanya terbatas melalui radio, televisi, pensi di sekolah, greeting, undangan seminar, talkshow namun juga melalui media sosial. Sony Music mengakui apabila dalam melakukan rekaman lagu dan promosi menjadi lebih ketat dikarenakan materi atau musik yang sulit untuk memetakan pasar dikarenakan banyaknya platform yang dapat mengakomodir sebuah musik dan Sony Music ikut andil agar tidak tertinggal dengan pasar musik yang ada sekarang. ${ }^{4}$

\section{Ruang Lingkup Perjanjian Kerjasama Rekaman Artis dan Perjanjian Manajemen Artis}

Untuk menjalin suatu kerjasama di bidang industri musik dengan artis-artisnya, Sony Music mengatur kegiatan tersebut dalam perjanjian tertulis. Perjanjian yang

\footnotetext{
${ }^{3}$ https://www.liputan6.com/showbiz/read/2506369/10-fakta-mencengangkan-industri-musik-yang-perlu-anda-ketahui diakses pada tanggal 29 April pukul 09.11

4 https://www.viva.co.id/gaya-hidup/829195-terkepung-industri-musik-digital diakses pada tanggal 5 Maret 2018 pukul 12.10
} 
dimaksud meliputi perjanjian rekaman artis yang menjadi induk perjanjian dan perjanjian manajemen artis sebagai bagian dari induk perjanjian. Kedua perjanjian ini merupakan satu kesatuan dan tidak terpisah. Hal inipun dijelaskan dalam Pasal 14 Perjanjian Kerjasama Rekaman Artis No. 025/PR/SMEI/IV/16 yang berbunyi:

Pasal 14

\section{MANAJEMEN ARTIS}

4.2 Para pihak sepakat untuk menandatangani Perjanjian Manajemen Artis ("Perjanjian Manajemen Artis") yang akan mengatur lebih lanjut mengenai hak-hak dan kewajiban diantara para pihak terkait dengan aktivitas manajerial yang akan dilakukan oleh Sony Music. Perjanjian Manajemen Artis tersebut adalah merupakan bagian yang tidak terpisahkan dari perjanjian ini.

\section{Perjanjian Kerjasama Rekaman Artis}

Perjanjian rekaman artis merupakan induk perjanjian label rekaman Sony Music dengan artisnya yang mencakup hal - hal dasar terkait segala bentuk kegiatan kerjasama yang dilakukan oleh Sony Music dan artisnya. Makna perjanjian kerjasama rekaman artis tidak terlepas dari makna esensial yang dijelaskan dalam Pasal 1313 BW yakni merupakan suatu perbuatan dimana satu pihak atau lebih mengikatkan dirinya terhadap satu orang atau lebih. Dengan demikian perjanjian kerjasama rekaman artis menimbulkan perikatan diantara para pihak yang membuatnya sekaligus memuat konsekuensi - konsekuensi tertentu.

Dalam perjanjian ini terdapat beberapa bentuk kerjasama yang ditawarkan Sony Music seperti rekaman single dan pembagian royalti atas produksi rekaman single tersebut. Dari poin- poin yang terdapat dalam perjanjian dapat simpulkan bahwa Sony Music adalah pihak yang bertanggungjawab penuh atas segala kebutuhan dalam rangka mengelola kegiatan keartisan, sedangkan artis menjadi pihak yang harus selalu siap atas segala kegiatan tersebut. Dengan demikian kita dapat menilai bahwa perjanjian kerjasama rekaman artis dapat dikategorikan sebagai perjanjian tidak bernama. Jadi meskipun kontrak tak bernama tidak terdapat 
dalam BW pengaturannya, namun dalam pembentukan kontrak harus mengikuti dan memenuhi aturan umum lahirnya suatu kontrak sesuai dengan buku III BW. ${ }^{5}$

\section{Perjanjian Manajemen Artis}

Dalam dunia bisnis entertaiment terdapat perjanjian tambahan yang menjadi satu kesatuan dan melengkapi perjanjian kerjasama rekaman artis yaitu perjanjian manajemen artis. Perjanjian manajemen artis ini dapat dikategorikan sebagai perjanjian pemberian kuasa dikarenakan manajer atau manajemen artis bertindak mewakili artis dalam menetapkan syarat-syarat, penyusunan, penandatanganan atas penggunaan pekerjaan atau eksploitasi talenta artis maupun jasa-jasanya, melakukan konsultasi dan negosiasi harga serta memberi perspektif terhadap jasa pekerjaan artis, publikasi dan mitra kerja. ${ }^{6}$ Berdasarkan sifatnya, maka dalam perjanjian pemberian kuasa yang demikian dapat dikatakan sebagai perjanjian sepihak. Perjanjian sepihak merupakan perjanjian yang selalu menimbulkan kewajiban hanya bagi satu pihak. ${ }^{7}$

Bentuk perjanjian manajemen artis sendiri relevan dan bersinggungan dengan ketentuan yang terdapat dalam Pasal 1792 BW yang menjelaskan bahwa perjanjian pemberian kuasa merupakan perjanjian dimana seorang memberikan kekuasaan kepada seorang lain, yang menerimannya, untuk atas namanya menyelenggarakan suatu urusan. Namun, ternyata perjanjian manajemen artis tidak sebatas perjanjian pemberian kuasa dikarenakan Sony Music memberikan perluasan klausula mengenai hakikat perjanjian manajemen artis. Dalam rangka melengkapi perjanjian kerjasama rekaman artis, perjanjian manajemen artis juga menerapkan sistem "kerjasama." Hal ini ditegaskan dalam tugas manajerial yang berperan untuk membantu artis memperoleh pekerjaan, memberikan nasihat-nasihat, serta membantu mempromosikan artis. Adapun dalam rangka kerjasama ini terdapat

\footnotetext{
${ }^{5}$ Ibid.[4].

${ }^{6}$ https://squarefightstar.wordpress.com/2011/02/23/perjanjian-dalam-manajemen-artis/ diakses pada tanggal 01 Maret 2018 pukul 15.12

7 Salim, Hukum Kontrak Teori dan Teknik Penyusunan Kontrak, Sinar Grafika.[29].
} 
kompensasi pembagian hasil antara artis dan manajer (Sony Music) atas pekerjaan yang dilaksanakan artis yang berasal dari upaya pemasaran pihak manajer. Hal ini dijelaskan dalam Pasal 5 Perjanjian Manajemen Artis No: 025/PM/SMEI/IV/16.

\section{Keabsahan Perjanjian Kerjasama Rekaman dan Perjanjian Manajemen Artis}

Dalam membuat sebuah perjanjian tidak hanya kata sepakat yang digunakan sebagai dasar namun juga diperlukan pemenuhan persyaratan lainnya sebagai bentuk keabsahan dari ketentuan-ketentuan yang terdapat dalam Pasal 1320 BW. Untuk mencapai suatu keabsahan perjanjian haruslah memenuhi keempat unsur secara kumulatif yang terdapa dalam Pasal 1320 BW. Adapun dalam keempat syarat tersebut dapat diringkas dalam dua bagian yakni syarat subyektif dan syarat obyektif. Termasuk syarat subyektif yakni kesepakatan dan kecakapan karena berkaitan dengan personality subyek hukum yanhg dapat dinilai secara subyektif berdasarkan kriteria yang ditentukan membawa implikasi pada suatu kontrak yang tidak memenuhi salah satu syarat ini maka dapat dibatalkan (vernietegbaar). ${ }^{8}$ Berbeda halnya yang termasuk syarat obyektif yakni obyek tertentu dan kuasa yang diperbolehkan, suatu kontraktidak memenuhi syarat ini maka kontrak tersebut batal demi hukum (nieteg) karena apabila suatu kontrak tidak memiliki obyek maka tidak ada atau tidak jelasnya prestasi yang dilakukan para pihak. ${ }^{9}$ Begitu pula halnhya suatu kontrak memiliki suatu sebab yang bertentangan dengan perundang - undangan atau tidak memiliki sebab maka tujuan yang ingin dicapai oleh kontrak itu tidak terwujud dengan baik. ${ }^{10}$

\section{Asas dalam Perjanjian Kerjasama Rekaman Artis dan Perjanjian Manajemen Artis}

Pada perjanjian yang bernama ataupun perjanjian yang tidak bernama harus memenuhi asas-asas yang diperlukan untuk membuat perjanjian yaitu;

a. Asas konsensualisme

\footnotetext{
8 Y. Sogar Simamora, Faizal Kurniawan, dan Erni Agustin, Op.Cit.[31].

9 ibid

10 ibid
} 
Asas ini berkaitan dengan syarat sah perjanjian yang terdapat dalam Pasal 1320 BW yaitu kesepakatan antara para pihak (consensus). Dalam kesepakatan ini biasanya terjadi persesuaian kehendak dari masing-masing pihak yang kemudian terjadi persetujuan. Asas ini sangat erat hubungannya dengan asas kebebasan mengadakan perjanjian. ${ }^{11}$ Arti asas konsensualisme ialah pada dasarnya perjanjian yang timbul karenanya itu sudah dilakukan sejak detik tercapainya kesepakatan. ${ }^{12}$

b. Asas kebebasan berkontrak (freedom of contract)

Asas ini diatur dalam Pasal 1338 ayat (1) BW yang menyatakan "semua perjanjian yang dibuat secara sah berlaku sebagai undang-undang bagi mereka yang membuatnya." Dalam asas ini memberikan kebebasan kepada seseorang untuk secara bebas menentukan bentuk, jenis dan isi perjanjian. Memang kebebasan ini bukannya tanpa batas, rambunya adalah asal kontrak yang dibuat tidak bertentangan dengan ketertiban umum, perundangundangan dan kepatutan. ${ }^{13}$

c. Asas Daya Mengikatnya Perjanjian (pacta sunt servanda)

Menurut Pasal 1338 ayat (1) BW, asas daya mengikatnya perjanjian yang terdapat dalam pasal ini dapat diartikan bahwa segala apa yang telah diperjanjikan oleh para pihak harus dipenuhi bagaikan undang-undang yang telah mereka buat. Asas ini memberikan kepastian hukum bagi para pihak yang membuatnya dan menjamin rasa keadilan. ${ }^{14}$

d. Asas privity of contract

Perjanjian mengikat para pihak sendiri adalah logis, dalam arti hak dan kewajiban yang timbul dalam perjanjian tersebut hanya mengikat para pihak itu sendiri. Di dalam Pasal 1315 BW menyatakan "Pada umumnya tak seorang dapat mengikatkan diri atas nama sendiri atau meminta ditetapkannya suatu janji 2007.[4].

${ }_{11}$ Ahmadi Miru, Hukum Kontrak Perencanaan Kontrak, Raja Grafindo Persada, Jakarta,

Subekti, Hukum Perjanjian, Intermasa, Jakarta, 1987.[15]..

${ }_{13}$ Moch. Isnaeni, Op.Cit.[15].

${ }^{14}$ Leonora Bakarbessy dkk, Op.Cit.[101]. 
dari pada untuk dirinya sendiri. Jadi Pasal 1315 BW menyimpulkan bahwa orang tidak dapat meletakkan kewajiban bagi orang lain tanpa sepakatnya. ${ }^{15}$

e. Asas itikad baik

Asas itikad baik merupakan landasan suatu perjanjian dan mempunyai peran yang cukup penting. Asas itikad baik ini tertuang dalam Pasal 1338 ayat (3) BW yang menyatakan bahwa "semua perjanjian harus dilaksanakan dengan itikad baik.". Itikad baik ini harus dianggap menjiwai keseluruhan tahapan terjadinya proses perjanjian, tidak saja pada saat pelaksanaan, tetapi juga pada waktu pra perjanjian dan pada waktu penutupan perjanjian. ${ }^{16}$ Maksud dari itikad baik, bahwa cara menjalankan suatu perjanjian tidak boleh bertentangan dengan kepatutan dan keadilan. ${ }^{17}$

f. Asas proporsionalitas

Hubungan kontrak komersial (bisnis) dari para pihak tentunya mengandung kepentingan masing - masing. Dengan asumsi dasar bahwa karakteristik kontrak komersial menempatkan posisi para pihak pada kesetaraan, sehingga tujuan para kontrakan yang berorientasi pada keuntungan bisnis akan terwujud apabila terdapat pertukaran hak dan kewajiban yang fair (proporsional) ${ }^{18}$ Pada dasarnya asas proporsionalitas merupakan perwujudan dari doktrin "keadilan berkontrak" yang mengoreksi dominasi atas kebebasan berkontrak yang dalam beberapa hal justru menimbulkan ketidakadilan. ${ }^{19}$

\section{Para Pihak Dalam Perjanjian Kerjasama Rekaman Artis dan Perjanjian Manajemen Artis}

Hubungan hukum yang terjadi antara Sony Music dengan artisnya ini menimbulkan kewajiban dan hak yang berasal dari perjanjian kerjasama. Menurut Subekti bahwa perjanjian kerjasama hanya mempunyai daya hukum intern (ke

\footnotetext{
15 Ibid. [103]..

${ }^{16}$ Moch. Isnaeni, Op.Cit.[17].

${ }_{17}$ Subekti II, Pokok-Pokok Hukum Perdata, Intermasa, Jakarta, 2011.[139]..

${ }_{18}$ Agus Yudha Hernoko, Op.Cit.[84]..

19 Ibid.[87].
} 
dalam) dan tidak mempunyai daya hukum keluar. Yang bertindak keluar dan bertanggung jawab kepada pihak ketiga adalah kerugian diantara para sekutu diatur dalam perjanjiannya, yang tidak perlu diketahui masyarakat. ${ }^{20}$ Para pihak yang termasuk dalam masing - masing perjanjian dapat dielaborasikan sebagai berikut.

> Para Pihak dalam Perjanjian Kerjasama Rekaman Artis

\section{a. Label Rekaman}

Atas dasar kepentingan pembuatan rekaman lagu yang terjadi antara Sony Music dengan artisnya maka munculah suatu hubungan kerjasama yang kewajiban dan haknya diatur dalam Pasal 2, Pasal 5 dan Pasal 7 Perjanjian Kerjasama Rekaman Artis No. 025/PR/SMEI/IV/16. Dalam perjanjian kerjasama rekaman artis ini muncul kewajiban bagi Sony Music untuk melakukan rekaman lagu dan pembuatan video klip menggunakan jasa Sony Music, memberikan royalti kepada artis, membayar pembayaran atau akomodasi terhadap artis selama melakukan kegiatan promosi lagu dan wajib melakukan promosi terhadap lagu artis sedangkan untuk hak, Sony Music memiliki hak ekslusif untuk memperjualbelikan lagu artis, hak untuk melakukan promosikan terhadap pihak ketiga dan dibebaskan dari segala tuntutan yang berkaitan dengan perjanjian rekaman artis.

b. Artis

Artis dalam hal ini merupakan pihak yang berkewajiban untuk memberikan sesuatu kepada pihak lain yaitu berupa rekaman suara atau karya musik dengan menggunakan jasa Sony Music. Untuk menggunakan jasa rekaman yang dimiliki oleh Sony Music maka artis harus mematuhi hak dan kewajiban yang dituangkan dalam perjanjian kerjasama tersebut. Ketentuan yang mengatur mengenai hak dan kewajiban artis terdapat dalam Pasal 6, Pasal 7, dan Pasal 8 Perjanjian Kerjasama Rekaman Artis No. 025/PR/SMEI/IV/16. Selain kewajiban untuk melakukan rekaman suara dengan Sony Music, artis juga memiliki kewajiban untuk memberikan waktunya selama jangka waktu

\footnotetext{
${ }^{20}$ Subekti III, Aspek-aspek Hukum Perikatan Nasional, Alumni, Bandung, 1976.[53].
} 
tertentu untuk melakukan promosi lagu bersama dengan Sony Music, tidak melakukan promosi tanpa seijin Sony Music dan melakukan tuntutan terhadap Sony Music, sedangkan hak yang dimiliki oleh artis yaitu pembayaran royalti, pembayaran jasa apabila melakukan promosi yang dibayar dan pembayaran akomodasi serta transportasi untuk melakukan promosi.

Dalam hal ini artis yang melakukan perjanjian kerjasama dengan Sony Music tidak dapat melakukan persesuaian kehendak atas perjanjian kerjasama yang dibuatnya dikarenakan pihak Sony Music telah mempunyai bentuk bakunya. Istilah perjanjian baku dalam bahasa Belanda dikenal dengan standard voor vaardeen, dalam bahasa Inggris dikenal dengan standart contract. Standart kontrak merupakan perjanjian yang telah ditentukan dan telah dituangkan dalam bentuk formulir, kontrak ini ditentukan secara sepihak oleh salah satu pihak, terutama pihak ekonomi kuat terhadap pihak ekonomi lemah. ${ }^{21}$ Sebagai suatu proses, kontrak yang ideal seharusnya mampu mewadahi pertukaran kepentingan para pihak secara fair dan adil (proporsional) pada setiap fase atau tahapan kontrak. ${ }^{22}$ Sebagaimana diketahui bahwa untuk sampai pada tahapan perjanjian atau kontrak, para pihak pada umumnya melakukan tahapan negosiasi agar tercapai kesepakatan..$^{23}$

$>$ Para Pihak dalam Perjanjian Manajemen Artis a. Manajer

Dalam perjanjian manajemen artis, Sony Music menyediakan satu orang manajer yang bertindak mewakili Sony Music guna mengelola segala bentuk kegiatan artis yang bersifat komersial termasuk pekerjaan artis. Pekerjaan sebagaimana dijelaskan pada Pasal 4.1 huruf a Perjanjian Manajemen Artis No : 025/PM/SMEI/IV/16 bukanlah termasuk dalam perjanjian kerja akan tetapi perjanjian melakukan pekerjaan tertentu. walapun dalam klausula terdapat

${ }^{21}$ Salim II, Perkembangan Hukum Kontrak di Luar KUH Perdata, Raja Grafindo Perkasa, Jakarta, 2006.[145].

22 Agus Yudha Hernoko, Op.Cit.[148]..

${ }^{23}$ Ibid.[150]. 
kewajiban manajer untuk membantu mencarikan pekerjaan terhadap artis akan tetapi dalam hal ini manajer bukanlah majikan dan artis bukanlah buruh karena pekerjaan yang dilakukan oleh artis bukan di bawah pimpinan manajer. Adanya pekerjaan ialah hanya jika ia bekerja di bawah pimpinan pihak lain, dan adanya majikan hanya jika ia memimpin pekerjaan yang dilakukan oleh pihak kesatu. ${ }^{24}$ Selain itu, manajer juga berhak untuk bertindak mewakili artis.

b. Artis

Melanjutkan penjelasan di atas mengenai perjanjian untuk melakukan pekerjaan tertentu, maka artis dapat memposisikan diri sebagai pihak yang melaksanakan pekerjaan tersebut. Dalam perjanjian untuk melakukan jasa jasa tertentu, suatu pihak menghendaki dari pihak lawannya dilakukan suatu pekerjaan untuk mencapai suatu tujuan, untuk mana ia bersedia membayar upah, sedangkan apa yang akan dilakukan untuk mencapai tujuan tersebut sama sekali terserah pada pihak lawan itu. Biasanya pekerjaan lawan ini adalah seorang ahli dalam melakukan pekerjaan tersebut dan biasanya juga sudah memasang tarif untuk jasanya itu. Upahnya biasanya dinamakan honorarium.

Selanjutnya perjanjian manajemen artis dalam kaitanya sebagai perjanjian pemberian kuasa, artis bertindak sebagai pemberi kuasa. Dalam hal ini biasanya pemberi kuasa memberikan kuasa kepada penerima kuasa untuk mewakilinya, baik diluar pengadilan maupun di muka pengadilan. ${ }^{25}$

\section{Berakhirnya Perjanjian Kerjasama Artis dan Perjanjian Manajemen Artis}

Dalam keberlakuan perjanjian kerjasama rekaman artis dan perjanjian manajemen artis masing - masing memiliki ketetapan waktunya sendiri - sendiri. Hal ini dikaitkan dengan bentuk kesepakatan antara Sony Music dengan artisnya apakah hanya berupa produksi single (satu lagu) atau berupa hak opsi album yang akan dijelaskan secara rinci sebagai berikut:

I. Berakhirnya Perjanjian Kerjasama Rekaman Artis

\footnotetext{
${ }^{24}$ Lanny Ramli, Hukum Ketenagakerjaan, Airlangga University Press, Surabaya, 2008.[23].

${ }_{25}$ Salim, Op.Cit, [85].
} 
Dalam Pasal 4 Perjanjian Kerjasama Rekaman Artis No. 025/PR/SMEI/ IV/16 tentang jangka waktu dan pengakhiran perjanjian, Sony Music menetapkan jangka waktu satu tahun sejak dirilisnya single pertama, sedangkan untuk hak opsi album adalah tiga tahun sejak dikeluarkannya surat penggunaan hak opsi oleh Sony Music. Lebih lanjut dalam Pasal 4.3 Perjanjian Kerjasama Rekaman Artis No. 025/PR/SMEI/IV/16 Sony Music juga menjelaskan bahwa perjanjian ini bata dengan sendirinya dalam hal:

a) Habisnya jangka waktu perjanjian,;

b) Adanya pengajuan proses hukum baik secara sukarela ataupun tidak sukarela sehubungan dengan kebangkrutan, insolvensi, pembubaran badan hukum, atau renegosiasi atas salah satu pihak dalam perjanjian ini;

c) Terpenuhinya semua ketentuan dalam perjanjian ini.

II. Berakhirnya Perjanjian Manajemen Artis

Seperti yang dijelaskan sebelumnya bahwa perjanjian manajemen artis merupakan perjanjian yang melengkapi perjanjian kerjasama rekaman artis sekaligus menjadi satu kesatuan, maka dalam Pasal 8 Perjanjian Manajemen Artis No: 025/PM/SMEI/IV/16 masa manajerial Sony Music dalam kesepakatan produksi single ialah satu tahun dan tiga tahun untuk hak opsi album. Namun apabila Sony musik membatalkan hak opsi album yang telah disepakati, perjanjian manajerial artis tetap terus berlaku selama tiga tahun terhitung sejak pembatalan hak opsi tersebut dilayangkan.

Sony Music merupakan perusahaan rekaman terbesar di Indonesia mengadakan perjanjian kerjasama rekaman artis dengan artisnya untuk melakukan rekaman hasil karyanya berupa suara dan video klip menggunakan jasa Sony Music serta mengganti biaya akomodasi dan transportasi artis untuk kepentingan promosi sesuai dimana tempat artis tersebut tinggal. Namun, selama jangka waktu perjanjian, Sony Music tidak memenuhi kewajibannya dalam pembuatan video klip sebagai salah satu bentuk promosi dan penggantian biaya-biaya yang dikeluarkan artis untuk kepentingan promosi yang terdapat dalam Pasal 2 Perjanjian Kerjasama Rekaman Artis No. 025/PR/SMEI/IV/16 
untuk pembuatan video klip sehingga merugikan artis yang menggunakan jasa Sony Music tersebut.

Tindakan wanprestasi yang dilakukan oleh Sony Music termasuk dalam bentuk wanprestasi yang tidak melakukan prestasi sama sekali. Adanya sebuah bentuk tindakan wanprestasi yang dilakukan oleh Sony Music kepada artisnya dalam perjanjiannya maka pihak yang dirugikan dapat melakukan sebuah tuntutan sesuai dengan Pasal 1267 BW.

Selain itu, atas Perjanjian Manajemen Artis No. 025/PR/SMEI/IV/16 terjadi tindakan wanprestasi yang dilakukan oleh Sony Music Entertainment yang dianggap merugikan artis dikarenakan tidak memenuhi ketentuan yang terdapat dalam Pasal 4 Perjanjian Manajemen Artis Artis No. 025/PR/SMEI/IV/16. Tindakan wanprestasi Sony Music yang dianggap merugikan ialah tidak membantu artis dalam memperoleh pekerjaan dan bernegosiasi untuk kepentingan tersebut serta membantu karir artis dengan memberi nasihat, konsultasi dan arahan untuk perjalanan karir profesionalnya sebagai artis. Selama perjanjian berlangsung, manajeman artis tidak pernah memberikan nasihat, konsultasi atau arahan atas karir profesional artis sehingga artis merasa dirugikan atas tindakan manajemen artis.

Berdasarkan hal diatas, tugas yang telah disanggupi oleh manajemen artis harus dilaksanakan sebaik-baiknya dan dalam waktu yang setepatnya. Jika tidak, si penerima kuasa dapat dianggap melalaikan kewajibannya, untuk mana ia dapat dituntut mengganti kerugian yang ditimbulkan karena kelalaian itu. Hal ini sesuai dengan yang terdapat dalam Pasal $1801 \mathrm{BW}$, si penerima kuasa tidak hanya bertanggung jawab tentang perbuatan-perbuatan yang dilakukan dengan sengaja, tetapi juga tentang kelalaian-kelalaian yang dilakukan dalam menjalankan tugasnya.

\section{Bentuk Tanggungguat Sony Music terhadap Tindakan Wanpretasi atas perjanjian Kerjasama Rekaman Artis dan Perjanjian Manajemen Artis}

Tindakan wanprestasi yang dilakukan oleh Sony Music kepada artisnya dalam Perjanjian Kerjasama Rekaman Artis No. 025/PR/SMEI/IV/16 dapat dimintai pertanggungjawaban sesuai dengan tuntutan si artis sebagai pihak yang 
dirugikan. Artis dapat melakukan tuntutan kepada Sony Music untuk melakukan pemenuhan prestasi sesuai dengan yang terdapat dalam Pasal 1267 BW. Jika dalam hal ini, artis yang merasa dirugikan oleh tindakan wanprestasi Sony Music dapat melakukan tuntutan kepada Sony Music untuk memenuhi pelaksanaan perjanjian disertai ganti kerugian yang diderita sebagai akibat dari tindakannya. Menurut Pasal 1236 BW, unsur-unsur yang terdapat dalam ganti rugi ialah biaya, kerugian dan bunga.

Namun, dalam Perjanjian Kerjasama Rekaman Artis No. 025/PR/SMEI/ IV/16 tidak mengatur mengenai jumlah ganti kerugian atau denda yang diberikan kepada Sony Music apabila tidak melaksanakan kewajiban-kewajiban sesuai dengan yang terdapat dalam perjanjian. Oleh karena itu, tindakan wanprestasi yang dilakukan oleh Sony Music menimbulkan kerugian secara materiil dan immateriil. Kerugian materiil yang ditanggung oleh artis adalah terkait dengan biaya akomodasi dalam rangka promosi single selama masa perjanjian, sedangkan kerugian immateriil ialah mengenai pemenuhan kewajiban Sony Music untuk membuat video klip bersama dengan artisnya guna menunjang promosi single. Sedangkan, menurut Pasal 4 Perjanjian Manajemen Artis No. 025/PM/SMEI/ IV/16, Sony Music dalam melaksanakan perjanjian pemberian kuasa tidak melaksanakan tugas-tugas pemberian kuasa yang diberikan kepadanya dengan baik sehingga merugikan artis sebagai pemberi kuasa. Dalam melaksanakan perjanjian pemberian kuasa, Sony Music tidak melaksanakan negosiasi pekerjaan artis dengan baik sehingga merugikan artis untuk mendapatkan pekerjaan sekaligus tidak memberikan arahan atau nasihat untuk karir profesional artis yang dimana dalam hal ini berpengaruh besar terhadap keuntungan yang seharusnya diterima oleh artis sebagai pihak yang memberikan wewenang kepada Sony Music untuk bertindak atas nama dirinya. Tindakan yang merugikan yang dilakukan oleh Sony Music ini menimbulkan kerugian secara financial yang dimana kerugian tersebut di dasarkan atas keuntungan yang seharusnya diterima oleh artis atas lima tawaran pekerjaan yang dterima artis yang telah disampaikan kepada manajer namun tidak mendapatkan persesuaian kehendak oleh Sony Music sebagai manajer artis. Oleh 
karena itu, Sony Music sebagai penerima kuasa wajib bertanggung jawab atas tindakan lalai yang dianggap merugikan oleh si pemberi kuasa yaitu artis sesuai dengan Pasal 1801 BW.

\section{Penyelesaian atas Tindakan Wanprestasi dalam Perjanjian Kerjasama Rekaman Artis dan Perjanjian Manajemen Artis}

Adanya pasal yang menyatakan melepaskan Sony Music untuk tidak melakukan tuntutan apabila tidak menjalankan kewajibannya tersebut juga tentu tidak dilandaskan pula atas asas itikad baik sesuai dengan asas-asas yang seharusnya terdapat dalam sebuah perjanjian. Sony Music sebagai pihak yang mendapatkan keuntungan akibat dilepaskannya hak menuntut artis kepada Sony Music apabila tidak melaksanakan perjanjian merupakan tindakan yang tidak dilandasi atas rasa kepatutan dan keadilan yang sesuai dengan asas itikad baik sehingga menciderai asas kebebasan berkontrak yang dianut oleh Pasal 1338 BW. Upaya hukum untuk melakukan tuntutan atas tindakan wanprestasi terdapat dua opsi yakni;

a. Penyelesaian melalui jalur litigasi (in court settlement)

b. Penyelesaian melalui jalur nonlitigasi (out of court settlement)

Namun, meskipun terdapat dua opsi untuk melakukan penyelesaian sengketa atas tindakan wanprestasi yang dilakukan oleh Sony Music maka yang dapat dilakukan oleh artis untuk melakukan tuntutan ialah melalui jalur litigasi. Penyelesaian sengketa melalui jalur non-litigasi tidak dimungkinkan dikarenakan dalam perjanjian yang terjalin antara Sony Music dengan artis tidak ada klausul mengatur mengenai penyelesaian sengketa yang dilakukan melalui arbitrase. Dalam penyelesaian sengketa melalui jalur nonlitigasi yang salah satunya melalui arbitrase, klausul arbitrase ini penting untuk menentukan kompetensi atau kewenangan yang dimiliki oleh arbitrase untuk menyelesaikan sengketa yang terjadi diantara para pihak. Oleh karena itu, jika penyelesaian sengketa melalui jalur litigasi yang dipilih maka artis dapat mengajukan gugatan ke Pengadilan Negeri dimana tergugat berada. 


\section{Kesimpulan}

Hubungan hukum yang terjadi dalam perjanjian kerjasama antara Sony Music dan artisnya merupakan hubungan yang saling menimbulkan hak dan kewajiban diantara para pihak. Timbulnya hak dan kewajiban yang terjadi diantara para pihak ini menimbulkan sifat timbal balik (obligatoir) sehingga para pihak memiliki kedudukan yang sama. Perjanjian kerjasama yang terjadi diantara para pihak ini memiliki kategori sebagai perjanjian innominaat (tidak bernama) sedangkan perjanjian manajemen artis yang terjadi diantara Sony Music dengan artisnya merupakan perjanjian nominaat (bernama) yang dikategorikan sebagai perjanjian pemberian kuasa. Dalam perjanjian manajemen artis, pihak Sony Music merupakan penerima kuasa yang diberikan kewenangan untuk melakukan tindakan hukum mewakili si pemberi kuasa sedangkan si pemberi kuasa adalah artis yang memberikan kuasa kepada penerima kuasa untuk bertindak mewakilinya.

Jika Sony Music sebagai debitur yang melakukan tindakan wanprestasi maka artis sebagai kreditur dapat mengajukan gugatan wanprestasi kepada Sony Music melalui jalur litigasi untuk menyelesaikan sengketa ke Pengadilan Negeri setempat. Bentuk tindakan wanprestasi yang dilakukan oleh Sony Music ini tidak melakukan kewajibannya untuk melakukan pembuatan video klip bagi artis serta tidak melakukan penggantian biaya akomodasi dan transportasi yang dikeluarkan oleh si artis sesuai dengan yang terdapat dalam perjanjian. Gugatan wanprestasi yang diajukan oleh artis dapat disertai dengan tuntutan yang terdapat dalam Pasal 1267 BW yaitu memaksa debitur untuk memenuhi perjanjian, melakukan pembatalan perjanjian disertai dengan penggantian biaya kerugian dan bunga sebagai bentuk ganti rugi atas tindakan wanprestasi yang dilakukan oleh Sony Music. Gugatan wanprestasi ini dapat diajukan kepada perjanjian kerjaasama sedangkan untuk perjanjian manajemen artis ini, Sony Music dapat diajukan gugatan untuk melakukan tuntutan atas kerugian yang diderita oleh artis selama Sony Music menjalankan kuasa dari artis untuk bertindak mewakilinya karena tidak sesuai dengan yang diperjanjikan. 


\section{Daftara Bacaan}

\section{Buku}

Abdulkadir Muhammad, Hukum Pengangkutan Niaga, Citra Aditya Bakti, Bandung, 2008.

Peter Mahmud Marzuki, Penelitian Hukum, Prenada Mediagroup, Jakarta, 2014.

Agus Yudha Hernoko, Hukum Perjanjian Asas Proporsionalitas dalam Kontrak Komersial, Kencana Prenamedia Group, Jakarta, 2014.

Lanny Ramli, Hukum Ketenagakerjaan, Airlangga University Press, Surabaya, 2008.

Y. Sogar Simamora, Faizal Kurniawan, Errni Agustin, Buku Ajar Hukum Kontrak, Universitas Airlangga, Surabaya, 2009.

Ahmadi Miru, Hukum Kontrak Perencanaan Kontrak, Raja Grafindo Persada, Jakarta, 2007.

J.H Niewenhuis, Pokok-Pokok Hukum Perikatan, (Terjemahan Djasadin Saragih), Surabaya, 1985.

Leonora Bakarbessy dkk, Buku Ajar Hukum Perikatan, Universitas Airlangga, Surabaya 2011.

Moch. Isnaeni, Perkembangan Hukum Perdata di Indonesia, Laksbang Grafika, 2013.

Salim, Hukum kontrak Teori dan Teknik Penyusunan Kontrak, Sinar Grafika, 2014.

Subekti, Hukum Perjanjian, Intermasa, Jakarta, 1987.

Subekti II, Pokok-Pokok Hukum Perdata, Intermasa, Jakarta, 2011.

Subekti III, Aspek-aspek Hukum Perikatan Nasional, Alumni, Bandung, 1976.

Subekti IV, Aneka Perjanjian, Citra Aditya Bakti, Jakarta, 2011.

Subekti V, Aneka Perjanjian, Citra Aditya Bakti, Bandung, 1995.

Yahya Harahap, Segi-segi Hukum Perjanjian, Alumni, Bandung, 1986. 


\section{Perundang-undangan}

Burgelijk Wetboek (BW).

Undang - Undang No. 28 Tahun 2014 tentang Hak Cipta

SEMA Nomor 3 Tahun 1963 tentang Gagasan Menganggap Burgerlijk Wetboek tidak sebagai Undang - Undang

\section{Skripsi}

Nadhia Amania Sadidha, Pemberian Ganti Rugi Delay PT. Lion Mentari Airlines Ditinjau dari UU No.1 Tahun 2009 tentang Penerbangan, Skripsi, Fakultas Hukum Universitas Airlangga, 2017.

\section{Situs Internet}

Viva News Entertainment, “Terkepung Industri Musik Digital,” https://www.viva. co.id/gaya-hidup/829195-terkepung-industri-musik-digital diakses pada tanggal 5 Maret 2018 pukul 12.10

Lembaga Manajemen Kolektif, "LMKN Diminta Urus Royalti Hingga Tempat Hiburan." http://lmkn.id/lmkn-diminta-urus-royalti-hingga-tempat-hiburan/ diakses pada tanggal 20 Juli 2018 pukul 22.00

Hukum Online, "Perjanjian Timbal Balik atau Perjanjian Sepihak?," http://www. hukumonline.com/berita/baca/hol19208/perjanjian-timbal-balik-atauperjanjian-sepihak diakses pada tanggal 3 Maret 2018.

HOW TO CITE: Alrido Pradanar, 'Tanggung Gugat Label Rekaman Dalam Perjanjian Kerjasama Rekaman Artis Dan Perjanjian Manajemen Artis' (2018) Vol. 1 No. 1 Jurist-Diction. 